\title{
イヌマキ枝葉油に就ての研究 第一報含有成分に就て
}

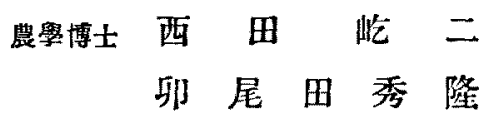

(昭和五年十月二十六日受理)

イヌマキ(Podocarpus macrophylla, Don.) は暖帶及熱帶に產する釷葉樹なるが 其枝葉油に就て著者（三浦，西田，小椋：林學會雜誌第 20 號 120 大正 12 年）は

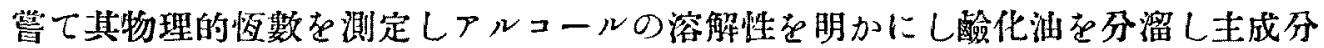
たる白色結晶につき少しく研究せるも試料少くして研究を中斷せるか偶名福同管 林局管內のイヌマキ造林の間伐あるを聞さたるを以て枝葉の拂下げを受け更に熊 本營林局へ枝葉探集を俅賴したるに都之城，高崎兩營林署上りの笴贈を受けたる につき其成分の研究に着手するここを得て荮に謹んで關係官廳に謝意を表す

イヌマキ枝葉油は三浦，辻雨氏（林學會雑誌第 3 號 40, 大正 9 年）に依り其收 量及比重を報告せられたるが今其收油率，物理的及化學的恆數を對比すれば狄表 の如!なる

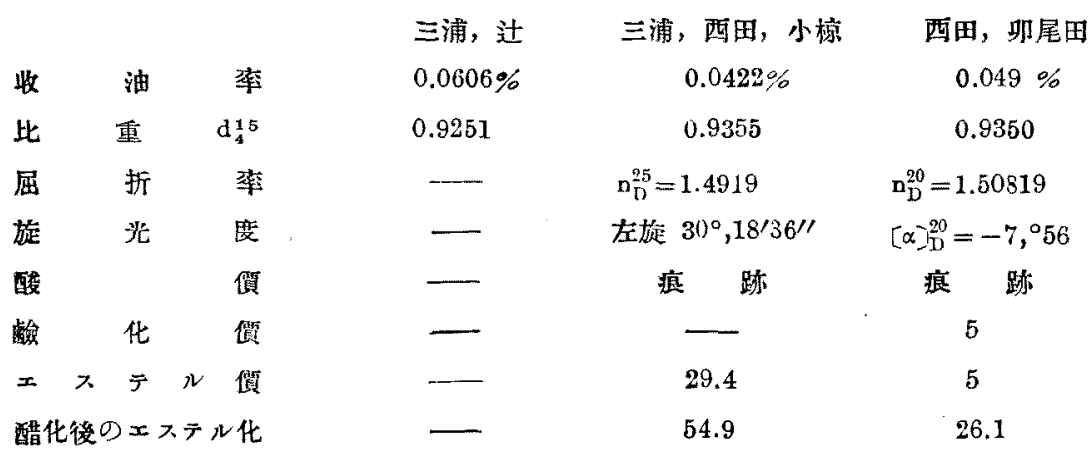

師ち三者收油率比重及屈折率は大美ない旋光度は何れる左旋性なれぞ著者等の 今包得てるものが遙に少なくエステル價及醋化後のエステル價も同樣に低いェス テル價より存在するェスラルの念有荤を想像するに

$$
\begin{array}{ccc}
\mathrm{C}_{10} \mathrm{H}_{13} \mathrm{O} の & \text { 醋酸エステルきして } & 1.74 \% \\
\mathrm{C}_{10} \mathrm{H}_{20} \mathrm{O} \text { の } & " \prime & 1.76 \%
\end{array}
$$




\begin{tabular}{|c|c|c|}
\hline $\mathrm{C}_{15} \mathrm{H}_{24} \mathrm{O}$ の & " & $2.32 \%$ \\
\hline $\mathrm{C}_{15} \mathrm{H}_{26} \mathrm{O} \quad 9$ & $" \prime$ & $2.34 \%$ \\
\hline
\end{tabular}

遊雇アルコールの含有萃を醋化後のエメテルより換算すれば

$\begin{array}{lcr}\mathrm{C}_{10} \mathrm{H}_{18} \mathrm{O} & \text { とて } & 7.33 \% \\ \mathrm{C}_{10} \mathrm{H}_{20} \mathrm{O} & \prime \prime & 7.43 \% \\ \mathrm{C}_{15} \mathrm{H}_{24} \mathrm{O} & \prime \prime & 10.47 \% \\ \mathrm{C}_{15} \mathrm{H}_{26} \mathrm{O} & \prime \prime & 10.57 \%\end{array}$

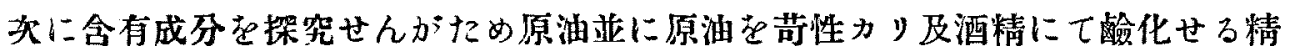
油を減壓下に分溜すれば實羷の部に記載するが如き各種溜分に分別し得らる此等 の分溜に訨り原油は溜叧 XII 及 XIII を主成分こし畧化油を之に相當して互に 類似せる VII' 乃至 $X^{\prime}$ を主成分さすること想像し得らる

溜分 XIII, IX'， $\mathrm{X}^{\prime}$ より結晶を得られたるが他の溜分は何れも油狀を呈して居る

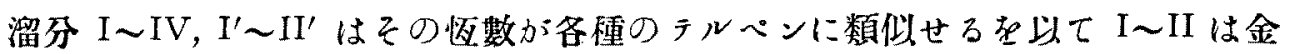
屬ナトリウムを加人 $\mathrm{CO}_{2}$ ガスを通じて分溜精製せるがその㤜數は炏表の如くで ある

\begin{tabular}{|c|c|c|c|c|c|}
\hline & 減 泟 & 温 度 & $D_{4}^{15}$ & $\mathrm{n}_{\mathrm{D}}^{20}$ & {$[\alpha]_{D}^{20}$} \\
\hline $\mathrm{I}-\mathrm{b}$ & $6 \mathrm{~m} . \mathrm{m}$ & $38-39^{\circ} \mathrm{C}$ & 0.8545 & 1.46787 & $+22^{\circ}, 0$ \\
\hline II-a & $5 \mathrm{~m} \cdot \mathrm{m}$ & $43-45^{\circ} \mathrm{C}$ & - & 1.46906 & $+40^{\circ}, 4$ \\
\hline II $-\mathrm{b}$ & $5 \mathrm{~m} \cdot \mathrm{m}$. & $47-48^{\circ} \mathrm{C}$ & - & 1.48536 & $+49^{\circ}, 86$ \\
\hline
\end{tabular}

a) 右旋性 $\propto$ ーピネン

I-b 及 II-a は恆數が右教性 $\alpha$-ビネンに近似せるを以てニトロソクロリッド及 ニトラールビベリヂンを作成せるに各ヶ $\mathrm{Smp} .103^{\circ} \mathrm{C}$ 及 $117 \sim 118^{\circ} \mathrm{C}$ の結晶を

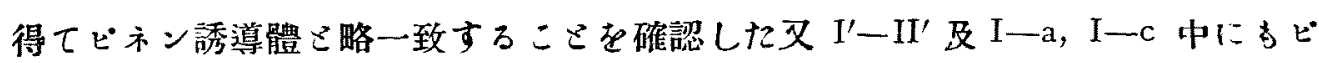
ネン誘導體を生じビネンの存在走確認することが出承た

b) カムフエン

溜分 III $\mathrm{Na}$ 加へて精製せるに $\mathrm{n}_{\mathrm{D}}^{20}=1.48249,[\boldsymbol{\alpha}]_{\mathrm{D}}^{20}=+51.96$ を示し溜分

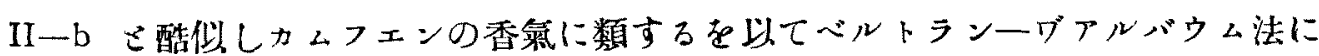

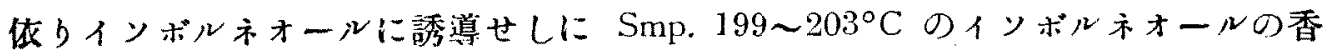

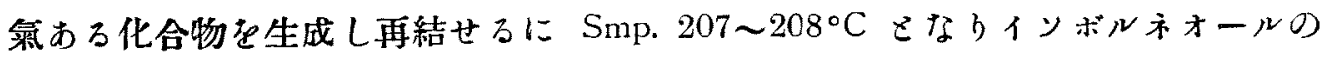
Smp. $212^{\circ} \mathrm{C} よ り$ 少し低きもインボルネネールの存在を確認し得可く其他にテル ベンアルコールの少量を混和するにおらすやや思はる

c) フェンーン 


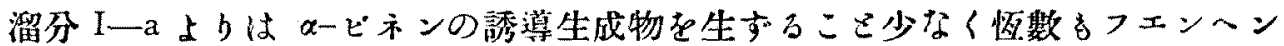
に類似せるが如〈思惟せらろ〉を以てカンフエン同樣インフェンヒールァルンー ルの生成を試みたれごも香氮稍類するのみで結晶は出承ない又ウレタンの誘導體

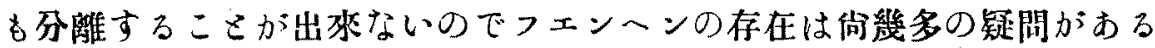

d) $\beta$ ーピネン

溜分 III〜IV は $\beta$-ビネンの恒數に類似するが故にノビン酸ンーダに酸化し稀 硫酸にてノビン酸さして結晶せしめ酒精，水にて數包再結せるに釙狀のノビン酸 の結晶を得られ Smp. $121 \sim 122^{\circ} \mathrm{C}$ で $126 \sim 127^{\circ} \mathrm{C}$ に達せざるるービンの存 在は明である

e) カヂネン

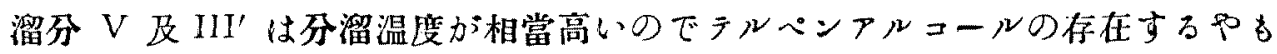
測られざるを以て酸素の含有量を測知せんため元素分析を行ひ次の結果を得たの である

$\begin{array}{ccccc} & & \mathrm{C} & \mathrm{H} & \mathrm{O} \\ \text { 溜 分 } \mathrm{V} & 86.94 \% & 11.93 \% & 1.13 \% \\ \text { 溜 分 } \mathrm{IIL} & 78.89 \% & 11.67 \% & 0.41 \%\end{array}$

即ち酸素の含有量は至つて少ない夘諭アルコール類の存在を否定するこさは出 来ない方大部分はテルペン類こ思惟せらるっを以て前同樣金屬 Naにて精製せる も $\mathrm{Na}$ とは餘り反㮣しない

この精製溜分に $\mathrm{HCl}$ 走添加したるに Smp. $118^{\circ} \mathrm{C}$ の針狀結晶を得られカヂネ シクロルヒドラートの融點さ一致しカデネンの存在走確認することが出來る又呈 色反雔によりてもカヂホンの存在走示すのである

f) カリオフイレン及シルベストレン

溜分 $\mathrm{V}$ 及 $\mathrm{II}^{\prime}$ はカリオフイレンの恒數さも近似すれミ゙カリオフイレンが存在 すればカヂネン同樣 $\mathrm{HCl}$ 添加物圶作りカリオフイレンクロールヒドラートの低 い熔融點尼寺すべき筈なれご極めてよくカヂネンの添加物ざ一致するが故にカ リオフイレンは存在せざるものつ如くシルベストレンも同樣の結論さなり其他二

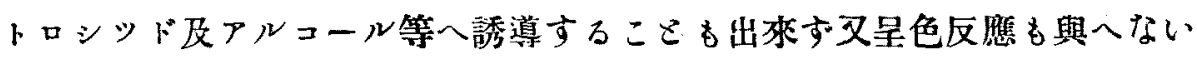

以上の實驗結果に佊りイヌマ枝葉油の低溫度にて溜出し棑る溜分中には右旋

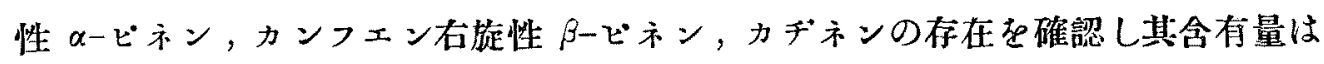
少量にて 4 成分古し合し $10 \%$ 内外であるへンフェン，カリオフイレン，シルぶス 
トレンは存在しない

溜分 VI及IV 以上の高級溜分の成叧及新しき化合物たるヂラルペン2租の性 狀等につきては第二献に詳誳するここ〉する

\section{藏 驗之 部}

I. 原料及收量

試料に供したるは熊本營林局管內福岡，都之城，高崎各營林署肉國有林產で䈏 森林化學教室にて蒸溜に附する前日枝を分ち小さき枝葉に細切したる後蒸溜稀に

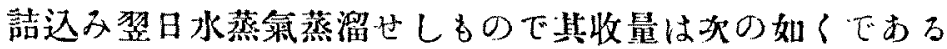

\begin{tabular}{|c|c|c|c|}
\hline 蒸溜月日 & $\begin{array}{c}\text { 原料詰込量 } \\
\mathrm{kg} .\end{array}$ & $\begin{array}{l}\text { 收 悬 } \\
\mathrm{g} .\end{array}$ & $\%$ \\
\hline $10 月 22 \mathrm{H}$ & 33.1 & \multirow{2}{*}{28} & \multirow{2}{*}{0.040} \\
\hline 23 & 37.4 & & \\
\hline 24 & 37.5 & 17 & 0.045 \\
\hline 25 & 37.8 & 18 & 0.047 \\
\hline 26 & 38.4 & 26 & 0.067 \\
\hline 28 & 37.9 & 16.7 & 0.045 \\
\hline 29 & 38.2 & 21.0 & 0.054 \\
\hline 30 & 38.2 & 22.0 & 0.057 \\
\hline 31 & 38.2 & 19.2 & 0.050 \\
\hline 11月 1日 & 38.2 & 21.0 & 0.054 \\
\hline 2 & 38.7 & 21.0 & 0.054 \\
\hline 4 & 38.5 & 22.0 & 0.057 \\
\hline 5 & 38.1 & 20.0 & 0.051 \\
\hline 6 & 38.8 & 19.0 & 0.048 \\
\hline 7 & 38.8 & 18.0 & 0.046 \\
\hline 8 & 41.6 & 20.0 & 0.048 \\
\hline 9 & 42.0 & 19.0 & 0.045 \\
\hline 11 & 42.0 & 19.0 & 0.045 \\
\hline 12 & 42.0 & 22.0 & 0.052 \\
\hline 13 & 42.0 & 20.0 & 0.047 \\
\hline 14 & 42.0 & 20.0 & 0.047 \\
\hline 15 & 42.0 & 17.0 & 0.041 \\
\hline 16 & 42.0 & 18.0 & 0.042 \\
\hline 18 & 36.7 & 20.0 & 0.054 \\
\hline 19 & 41.0 & 17.0 & 0.042 \\
\hline & & & 0.049 \\
\hline
\end{tabular}

II 物理 的 性 貿 
原油に硫酸ソーダを加へ乾嬠淽過するこきは黄褐色の精油を得, その物理的恒 數は次の如くである

a) 比重

$$
d_{4}^{15}=0.9347 \quad d_{4}^{15}=0.9352 \text { 平均 } 0.9350
$$

b) 旋 光 力

Landol-Lipich の旋光器に依 り $20^{\circ} \mathrm{C} に て$ 測定の結果

$$
[\alpha]_{10}^{20}=\frac{(-1.89)}{0.25 \times 1}=-7^{\circ}, 56
$$

c) 屈折率

Pulfrich の屈折計に依b測定し $20^{\circ} \mathrm{C} に \tau 34^{\circ}, 45^{\prime}$ t示したから $\mathrm{n}_{D}^{15}=1.50819$

III 化學的性質

a) 酸 價

試料 $0.9713 \mathrm{~g}$. 及 $0.9805 \mathrm{~g}$. 走 $150 \mathrm{c}$.c. のメスコルベンに取りアルコール。エ 一テル混液（1:1）50 c.c. 在加一溶解せしめ 1 c.c. のフェノールフタレンを和し 尚 $\mathrm{KOH}$ 液にて滴定せしに各夕潮く 0.1 c.c. 死要するのみである試料を加へざる ものに對照實驗をなせば 0.08 c.c. 索要するが故にイヌマキの䃽葉油の酸價は痕跡

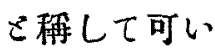

b) 鹼 化 價

試料 $1.0209 \mathrm{~g} ., 1.1529 \mathrm{~g}$. 及 $1.1300 \mathrm{~g}$. te $200 \mathrm{c.c}$. のマイヤーコルベンに容れ

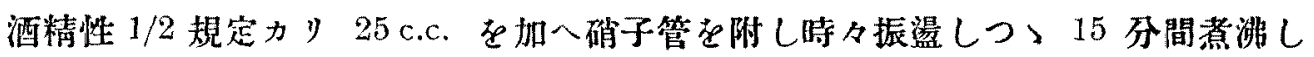

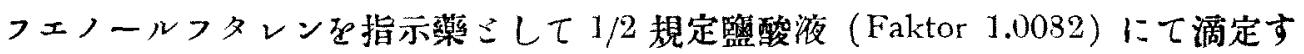
るときは 18.17 c.c., 18.33 c.c., 及 18.33 c.c. 在要す試料を用るることなく同一の

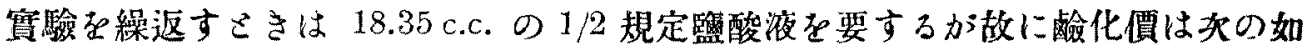
くる

$$
\begin{aligned}
& \text { ( } 1 \text { ) } \quad \frac{28.055 \times 1.0082 \times(18.35-18.17)}{1.0209}=4.99 \\
& \text { ( } 2) \quad \frac{28.055 \times 1.0082 \times(18.35-18.33)}{1.152 y}=4.91 \\
& \text { ( } 3) \quad \frac{28.055 \times 1.0082 \times(18.35-18.33)}{1.1300}=5.01 \\
& \text { 平 均 }=4.97
\end{aligned}
$$

郎ち醶化價は約 5 で酸價痕跡なればェステル㵋

c) 醌化後のエステル價 


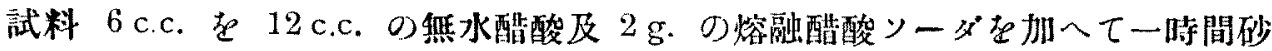

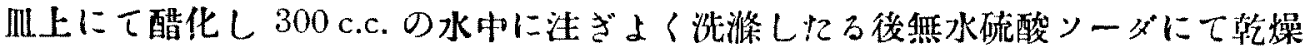
せる精油 $1.1067 \mathrm{~g}$. 及 $1.0086 \mathrm{~g}$. 取り遊離酸中和の後嘘化價測定こ同樣に處理 して醋化後のェステル價を测定せしに狄の結果を得た

$$
\begin{aligned}
& \frac{28.055 \times 1.0082(18.35-17.35)}{1.1607}=25.56 \\
& \frac{28.055 \times 1.0082(18.35-17.40)}{1.0086}=26.64
\end{aligned}
$$

VI 分 溜

\begin{tabular}{|c|c|c|c|c|c|c|c|}
\hline 溜分 & 䐎 & 溫＼cjkstart度 & $\%$ & 色 & $\mathrm{d}_{4}^{15}$ & $\mathrm{n}_{\mathrm{D}}^{20}$ & {$[\alpha]_{11}^{20}$} \\
\hline I & $6 \mathrm{~mm}$. & $42-44^{\circ}$ & 4.00 & 然 色 & 0.8555 & 1.46847 & $+28^{\circ} .02$ \\
\hline II & $5 \mathrm{~mm}$. & $46-18^{\circ}$ & 4.13 & " & 0.8513 & 1.47131 & $+46^{\circ} .40$ \\
\hline III & $5 \mathrm{num}$. & $56-60^{\circ}$ & 2.53 & 淡藏色 & 0.8572 & 1.47404 & $+57^{\circ} .58$ \\
\hline IV & $3 \mathrm{~mm}$. & $68-70^{\circ}$ & 0.70 & $"$ & - & 1.48613 & $+27^{\circ} .60$ \\
\hline V & $3 \mathrm{~mm}$. & $90-94^{\circ}$ & 1.07 & $" \prime$ & - & 1.49342 & $+1^{\circ} .40$ \\
\hline $\mathrm{VI}$ & $3 \mathrm{~mm}$. & $104-105^{\circ}$ & 1.31 & " & - & 1.49492 & $-5^{\circ} .72$ \\
\hline VII & $4 \mathrm{~mm}$ & $107-110^{\circ}$ & 9.05 & " & 0.9110 & 1.49596 & $-7^{\circ} .60$ \\
\hline VIII & $4 \mathrm{~mm}$. & $113-115^{\circ}$ & 2.93 & " & 0.9148 & 1.40417 & $-4^{\circ} .92$ \\
\hline IX & $3.5 \mathrm{~mm}$. & $110-112^{\circ}$ & 2.23 & "I & 0.9170 & 1.50096 & $-5^{\circ} .16$ \\
\hline $\mathrm{X}$ & $3.5 \mathrm{~mm}$. & $123-125^{\circ}$ & 3.13 & " & 0.9253 & 1.50591 & $-9^{\circ} .20$ \\
\hline $\mathrm{XI}$ & $3.5 \mathrm{~mm}$. & $138-140^{\circ}$ & 5.88 & $"$ & 0.9400 & 1.51062 & $-9^{\circ} .28$ \\
\hline XII & $3 \mathrm{~mm}$. & $153-169^{\circ}$ & 47.33 & " & 0.9710 & 1.52201 & $-13^{\circ} .32$ \\
\hline XIII & $3 \mathrm{~mm}$. & $173-177^{\circ}$ & 9.34 & $\prime \prime$ & 0.9873 & 1.52738 & $-40^{\circ} .92$ \\
\hline & & & & 来褐色 & & & \\
\hline
\end{tabular}

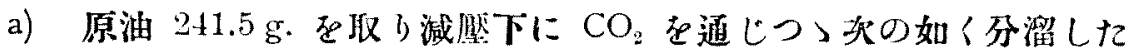

b) 噞化油の㞧溜

原油 $130 \mathrm{~g}$. を取り $170 \mathrm{~g}$. の酒精こ $10 \mathrm{~g}$. のカリに 3 時間噞化し Alkohol

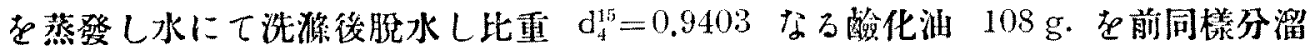

\begin{tabular}{|c|c|c|c|c|c|c|c|}
\hline 溜分 & 減 监 & 溫 度 & $\%$ & 色 & $\mathrm{d}_{4}^{1 ; 5}$ & $\mathrm{n}_{\mathrm{D}}^{20}$ & {$[\alpha]_{\mathrm{D}}^{20}$} \\
\hline $\mathrm{I}^{\prime}$ & $4.5 \mathrm{~mm}$ & $39-40 .^{\circ} 5$ & 7.10 & 热 色 & 0.8523 & 1.471016 & $+33^{\circ} .40$ \\
\hline II' & $5 \mathrm{~mm}$. & $45-47^{\circ}$ & 3.34 & "I & - & 1.472094 & $+54^{\circ} .64$ \\
\hline III' & $5 \mathrm{~mm}$ & $99-101^{\circ}$ & 5.74 & 淡㐙色 & 0.9040 & 1.493420 & $-1^{\circ} .00$ \\
\hline IV' & $4 \mathrm{~mm}$. & $104-106^{\circ}$ & 5.83 & " & 0.9099 & 1.498384 & $-9^{\circ} .40$ \\
\hline$V^{\prime}$ & $4.5 \mathrm{~mm}$ & $109-120^{\circ}$ & 8.08 & $\prime \prime$ & 0.9150 & 1.501606 & $-10^{\circ} .60$ \\
\hline $\mathrm{Vu}^{\prime}$ & $3 \mathrm{~mm}$. & $138-140^{\circ}$ & 10.24 & $" 1$ & 0.9483 & 1.514000 & $-11^{\circ} .52$ \\
\hline VII' & $2.5 \mathrm{~mm}$ & $156-157^{\circ}$ & 17.45 & $" \prime$ & 0.9687 & 1.520818 & $-20^{\circ} .60$ \\
\hline
\end{tabular}
して夯の結果存得た 


\begin{tabular}{|c|c|c|c|c|c|c|c|}
\hline VIII' & $2.5 \mathrm{~mm}$ & $157-158^{\circ}$ & 11.09 & 徽淡蒖色 & 0.9715 & 1.522624 & $-24^{\circ}, 00$ \\
\hline $\mathrm{IX}^{\prime}$ & $2.2 \mathrm{~mm}$ & $162-164^{\circ}$ & 13.93 & " & 0.9764 & 1.523815 & $-32^{\circ} .40$ \\
\hline$x^{\prime}$ & $2.2 \mathrm{~mm}$. & $164-165^{\circ}$ & 11.10 & 浓閔色 & 0.9828 & - & - \\
\hline $\mathrm{XI}^{\prime}$ & - & - & 1.03 & 然福色 & - & - & - \\
\hline
\end{tabular}

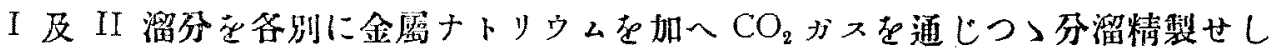

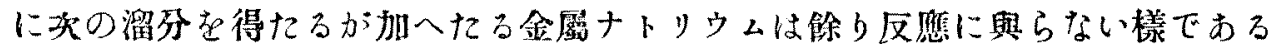
溜分I $6 \mathrm{~mm}$. の減壓にて分溜す

\begin{tabular}{|c|c|c|c|}
\hline 溜 分 & a & $36 \sim 37^{\circ} \mathrm{C}$ & \\
\hline$"$ & b & $38 \sim 39^{\circ} \mathrm{C}$ & 大部分濯出す \\
\hline$" \prime$ & $\mathrm{c}$ & $49 \sim 44^{\circ} \mathrm{C}$ & \\
\hline
\end{tabular}

溜分 I-b の物理的恓數は尔の如くである

$$
\mathrm{D}_{4}^{15}=0.8545 \quad \mathrm{n}_{\mathrm{D}}^{\mathrm{O} 0}=1.46 \mathrm{r} 87 \quad[\alpha]_{\mathrm{D}}^{20}=+22^{\circ} .0
$$

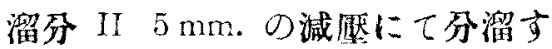

$$
\begin{aligned}
& \text { 溜分 a } 43 \sim 45^{\circ} \mathrm{C} \\
& \mathrm{n}_{D \lambda}^{20}=1.46906 \quad[\alpha]_{D}^{20}=+40^{\circ} .4 \\
& \text { 溜分 b } 47 \sim 48^{\circ} \mathrm{C} \\
& \mathrm{n}_{\mathrm{I}}^{20}=1.48536 \quad[\alpha]_{\mathrm{D}}^{20}=+49^{\circ} .86
\end{aligned}
$$

1) $\alpha$-Pinen

溜分 I-b 及 II-a はその崕數が右旋性 $\alpha$-Pinen に近似せるが故に夫々次の如 く誘導體尼作つた

$\mathrm{i}$ ニトロソクロリッド

試料 $1 \mathrm{~g}$. に亞俏酸アミール及水酷酸各 $1 \mathrm{~g}$. 加一食監及水にて上く洽却せる

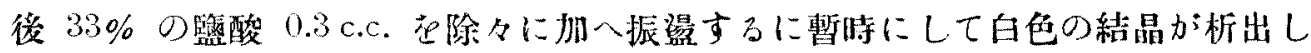
た之を吸引濾渦しタロ、フォルムに溶解せしめメタノールを加へて再結し硫酸乾

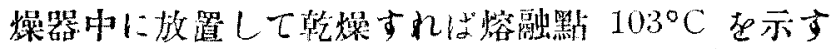

$$
\text { ii }
$$

試料 2 g.よりニトロソクロリッドを作夕丙容 100 c.c. のコハベンに取り過剩

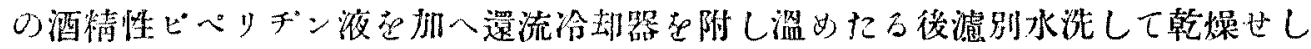
にSmp. 117〜 $118^{\circ} \mathrm{C}$ 老示す

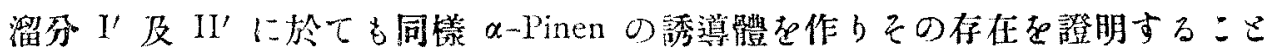
走得たのである

2) カム 


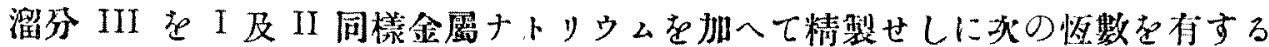
溜而水得らる

$$
\mathrm{n}_{\mathrm{D}}^{200}=1.48249 \quad[\alpha]_{\mathrm{D}}^{20}=+51^{\circ} .96
$$

溜分IIIは溜分 II-b と酷似せるが故に合して 4 g.ざなしべトランーヷアル バウム法に依り $10 \mathrm{~g}$. の水醰酸及 $0.4 \mathrm{~g}$. の $50 \%$ 硫酸を加八湯煎上に時々振燙

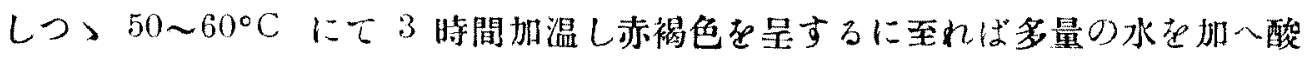
性反㦄の消失するまで海滌し酒精 $10 \mathrm{~g}$. 苛性力リ $2 \mathrm{~g}$. 专加八て 1 時間 $80^{\circ} \mathrm{C}$ に

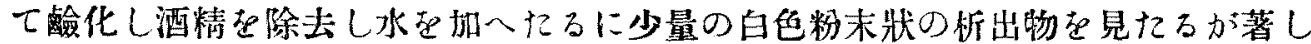

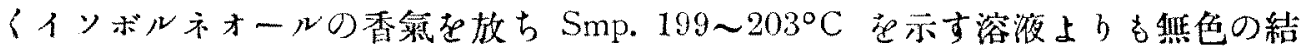
晶を得再結するに:Smp. $207 \sim 208^{\circ} \mathrm{C}$ の結晶を得インボルネオールの香氮が高い

3) フェンヘン

フメンヘンはカンフェン同㧼バルトラムーヷアルバウム法にてインフエンヒー

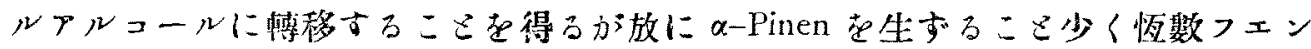
ーンに近しさ思はる溜分 I-a 及試みにI-b 溜分に同法を行ひしすインフェンヒ ールアルコール析出せずンボルホオールに類したる香骕するもりレタンの誘

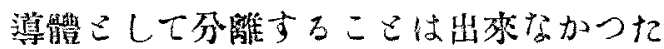

4) ß-ビ 京ン

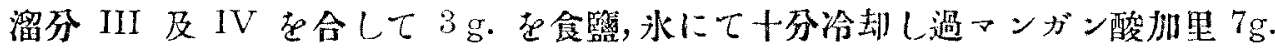

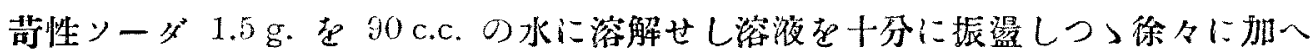
酸化せるが份不十分なるを以て延に溶波在追加して過マンガン酸カリの色を呈す

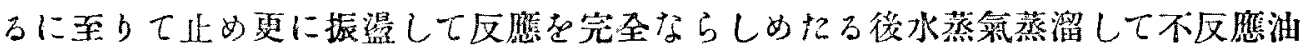

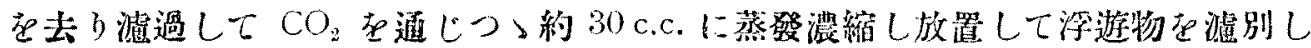

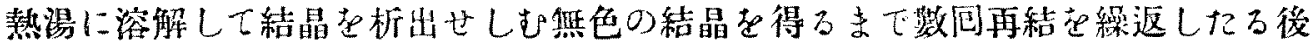

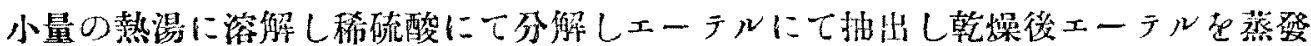
すれば針狀の結晶党生ずるこの Smp.は $110^{\circ} \mathrm{C}$.でするアルコール水にて再結す

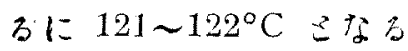

5) 力 ヂ 卒ン

溜分 $\mathrm{V}$ 及 $I I I^{\prime}$ が含酸素化合物なるや否や在知るため元素分析尼行ひ炏の結果 锝化

$$
\begin{gathered}
\text { 溜分 } \mathrm{V} \quad 0.1694 \mathrm{~g} . \text { より } \mathrm{CO}_{2}=0.5402 \mathrm{~g}, \mathrm{II}_{2} \mathrm{O}=0.1807 \mathrm{~g} . \\
\therefore \quad \mathrm{C}=86.94 \%, \mathrm{H}=11.93 \%, \quad \mathrm{O}=1.13 \%
\end{gathered}
$$


溜分 $\mathrm{II}^{\prime} 0.1782 \mathrm{~g}$ \& y $\mathrm{CO}_{2}=0.5743, \quad \mathrm{H}_{0} \mathrm{O}=0.1858 \mathrm{~g}$.

$$
\therefore \quad \mathrm{O}=87.89 \%, \quad \mathrm{H}=11.67 \%, \quad \mathrm{O}=0.44 \%
$$

師ら酸素含量少く含酸素化合物なきか或は微量に混和せる如く思惟せらるくを

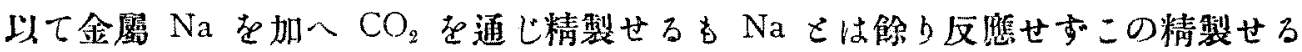

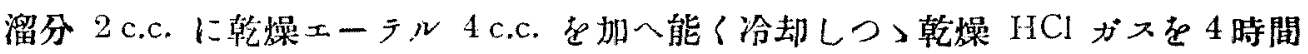

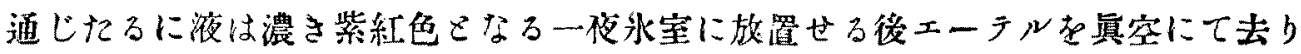
冷却しつつ3 日間放置すれぱ褐色の油狀物質中に多量の針狀結晶走析出し桃る之 を素燒板にて別方少量の㴘酒精にて再結したるにSmp. $118^{\circ} \mathrm{C}$ を示しカデネン デクロールヒドラートに一致す

前記溜分の 1 滴を過剩の水醋酸に溶かし濃厚硫酸一滴を滴下し振盪せるに强き

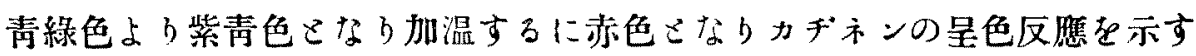

6) カリオフイレン及シルベストレン

$\mathrm{V}$ 及 III'の溜分はカリオフイレンの唒數を近似するも Dichlorhydrat はカヂ ホンの誘導體でカリオフイレンより由承せるSmp.の低いるのは得られない又 Caryophylennitrosit, Caryophylenalkohol 等の誘導故試みセれミ゙も生成しはい又シ ルベストレンの呈色反礁を示さず

(九大林化化學教室學街報告籍 14 號) 